Jurnal Neutrino Vol. 2, No. 2 Aprı 2010

\title{
PERANCANGAN DAN PEMBUATAN ALAT PENGENDALI ASAP ROKOK BERBASIS MIKROKONTROLER AT89S8252
}

\author{
Riza Mega Umami ${ }^{1}$
}

\begin{abstract}
Abstrak : Telah dibuat alat pengendali asap okok dengan sistem otomatis yang dapat mengembalikan kesegaran udara pada ruangan yang terpolusi asap rokok. Masukan dari sistem ini adalah sensor suhu LM35 yang dikuatkan dengan op-amp untuk mendapatkan perubahan tiap skala derajad celcius dan sensor asap TGS 2600. Masukan analog akan masuk ke ADC PCF8591 untuk mengubah sinyal analog dari sensor suhu dan sensor asap ke dalam bentuk digital. Keluaran dari ADC akan masuk dan diolah oleh Mikrokontroler AT89S8252. Selanjutnya mikrokontroler memerintahkan driver untuk mengaktifkan jendela, fan, alarm dan pengharum. Alat ini diharapkan dapat digunakan untuk mengendalikan zat beracun yang dikeluarkan melalui asap rokok dengan jalan mengendalikan asap rokok pada temperatur $32{ }^{\circ} \mathrm{C}$ dan konsentrasi asap $100 \mathrm{ppm}$, dimana kondisi ini sebagai keadaan kritis dalam suatu ruangan akibat asap rokok yang dikeluarkan.
\end{abstract}

Kata Kunci: Pengendali, Asap rokok, Otomatis

\section{PENDAHULUAN}

Kondisi pencemaran udara karena asap rokok akan berpengaruh bagi kesehatan manusia. Pengaruh yang paling utama berupa penularan penyakit bersifat airborne diseases (penyakit yang ditularkan melalui udara). Pencemaran udara ini akan berpengaruh terhadap angka kesakitan (morbidity) dan angka kematian (mortality) dari berbagai jenis penyakit. Tepatnya, polutan udara dapat menjadi sumber virus, bakteri, dan beberapa jenis cacing yang mendorong terjadinya penyakit polutan udara, sehingga mengakibatkan seseorang menjadi alergi yang selanjutnya menjadi pintu masuknya bakteri.

Analisis WHO (World Health Organization), badan organisasi kesehatan dunia menunjukan bahwa efek buruk asap rokok lebih besar bagi perokok pasif dibandingkan perokok aktif. Ketika perokok membakar sebatang rokok dan menghisapnya, asap yang dihisap oleh perokok disebut asap utama (mainstream) dan asap yang keluar dari ujung rokok (bagian yang terbakar) dinamakan asap sampingan (side steam). Asap sampingan ini terbukti mengandung lebih banyak hasil pembakaran tembakau dibandingkan pada asap utama. Asap ini mengandung Karbon Monoksida 5 kali lebih besar, Tar dan Nikotin 3 kali lipat, Amonia 46 kali lipat, Nikel 3 kali lipat, dan Nitrosamina (zat penimbul kanker) yang kadarnya mencapai 50 kali lebih besar pada asap sampingan

\footnotetext{
${ }^{1}$ Fisika UIN Maulana Malik Ibrahim Malang
} 
dibanding dengan kadar pada asap utama. Demikian juga zat-zat racun lainnya dengan kadar yang lebih tinggi terdapat pada asap sampingan.

Di Indonesia, perokok relative bebas mengisap rokok dimana saja. Kawasan bebas rokok di negeri ini masih amat minim, itupun masih mungkin di langgar karena sanksinya bisa dikatakan tidak ada. Sebagian perokok tidak memahami sikap toleransi pada ketidaknyamanan perokok pasif yang terpaksa mengisap asap rokok. Perokok pasif harus mencium bau bakaran tembakau sampai merasa sesak napas. Bahkan, pada sebagian perokok pasif yang sensitif akan langsung batuk-batuk saat itu juga.

Salah satu cara untuk mengurangi asap rokok agar tidak mengganggu orang lain yang tidak merokok, terutama dalam ruangan yang tidak memiliki area khusus untuk merokok, dibuatlah suatu alat yang dapat membantu membersihkan udara dalam ruangan terhadap polusi asap rokok. Alat ini diharapkan dapat mengatasi solusi tentang masalah polusi asap rokok yang terdapat dalam suatu ruangan.

\section{KAJIAN TEORI}

\section{Asap rokok}

Asap Rokok mengandung ribuan bahan kimia beracun dan bahan-bahan yang dapat menimbulkan kanker (karsinogen). Bahan berbahaya dan racun dalam rokok tidak hanya mengakibatkan gangguan kesehatan pada orang yang merokok (perokok aktif), namun juga pada orang-orang disekitarnya yang tidak merokok (perokok pasif), yang sebagian besar adalah bayi, anak-anak dan ibu-ibu, yang terpaksa menjadi perokok pasif karena ayah atau suami mereka merokok di rumah. Perokok pasif mempunyai resiko lebih tinggi untuk menderita kanker paru-paru dan penyakit jantung iskhemia. Sedangkan pada janin, bayi dan anak-anak, mempunyai resiko lebih besar untuk menderita bronchitis, pneumonia, berat badan rendah, infeksi rongga telinga dan asma (Tjandra, 1992: 4).

\section{Sensor Suhu}

Sensor suhu adalah alat yang digunakan untuk merubah besaran panas menjadi besaran listrik yang dapat dengan mudah dianalisis besarnya. Seri LM35 adalah IC sensor suhu yang presisi dimana tegangan keluarannya berbanding lurus dengan derajat suhu celcius (centrigade) sebesar $\pm 10 \mathrm{mV} /{ }^{\circ} \mathrm{C}$. jadi LM35 mempunyai keuntungan di atas sensor suhu yang dikalibrasi dalam Kelvin, sehingga dalam penggunaannya tidak perlu mengurangi nilai tegangan keluaran yang terlalu besar untuk mendapatkan skala centrigade yang sesuai.

\section{Sensor Asap}

Sensor adalah suatu piranti yang mengubah suatu besaran (Isyarat/energi) fisik menjadi besaran fisik lain, yang dalam hal ini pengubahan ke bentuk besaran elektrik. Pada sistem ini digunakan sensor gas yaitu sensor gas Figaro "TGS2600". Sensor ini mendeteksi senyawa kimia gas polutan, seperti $\mathrm{CO}_{2}, \mathrm{H}_{2}, \mathrm{CH}_{4}, \mathrm{CO}, \mathrm{HCN}$ dan lain-lain. 
Sensor tersebut dibuat dari plat baja nikel, kepala penutupnya terbuat dari plat baja $\mathrm{NiCu}$.

Rangkaian dasar sensor gas disajikan pada gambar 2.4. Tegangan (Vc) digunakan memberi energi elemen sensor yang mempunyai hambatan (Rs) antara dua elektroda sensor dan terhubung secara serial dengan resistor (RL). Sinyal sensor diukur secara tidak langsung melalui perubahan tegangan yang melewati hambatan $\mathrm{R}_{\mathrm{L}}$. Nilai Rs diperoleh daripersamaan berikut:

$$
R_{S}=\frac{V_{C} x R_{Z}}{V_{R E}}-R_{L}
$$

Dalam hal ini,

$$
\begin{aligned}
& \mathrm{R}_{\mathrm{L}}=\text { hambatan antara kedua elektroda pada sensor (Ohm) } \\
& \mathrm{V}_{\mathrm{C}}=\text { tegangan rangkaian (Volt) } \\
& \mathrm{V}_{\mathrm{RL}}=\text { tegangan keluaran (Volt) } \\
& \mathrm{R}_{\mathrm{S}}=\text { hambatan variabel sensor (Ohm). }
\end{aligned}
$$

\section{Pengkondisi sinyal}

Sinyal-sinyal listrik yang dihasilkan oleh transduser harus dikonversi ke dalam bentuk yang dikenali oleh papan akuisisi data yang dipakai. Tugas pengkondisi sinyal yang sering dilakukan adalah penguatan (amplification).

\section{ADC (Analog to Digital Converter)}

Konverter analog ke digital, dikenal luas dengan istilah ADC yang merupakan kependekan dari kata-kata asing analog to digital converter, banyak digunakan sebagai antarmuka antara rangkaian-rangkaian analog dengan mikrokontroler atau divais-divais dijital lainnya.(clayton,2005:240)

\section{Mikrokontroler AT89S8252}

Perbedaan mendasar antara mikrokontroler dengan mikroposesor adalah mikrokontroler selain memiliki Central Processing Unit (CPU) juga dilengkapi dengan memori, input-output yang merupakan kelengkapan sebagai minimum sistem mikrokomputer sehingga sebuah mikrokontroler dapat dikatakan sebagai mikrokomputer dalam keping tunggal (Single Chip Microcomputer) yang dapat berdiri sendiri.

Mikrokontroler AT89S8252 adalah mikrokontroler ATMEL yang kompatibel penuh dengan mikrokontroler keluarga MCS-51, membutuhkan daya yang rendah, memiliki performance yang tinggi dan merupakan mikrokontroler 8 bit yang dilengkapi kbyte flash PEROM (Programmable and eraseable Read Only Memory) yaitu ROM yang dapat ditulis menggunakan programmer. Serta 2 Kbyte EEPORM (Electrical Eraseable Programmable Read Only Memory) internal. Program memori dapat diprogram ulang dalam sistem atau dengan menggunakan programmer Nonvolately yang mempunyai kemampuan untuk ditulis ulang hingga 1000 kali dan berisikan perintah standart MCS-51 (Atmel. 1997:25). 


\section{LCD (Liquid Crystal Display)}

LCD adalah merupakan komponen optoelektronik yaitu komponen-komponen yang dikerjakan atau dipengaruhi oleh sinar (optolistrik), komponen-komponen pembangkit cahaya (light emiting) dan komponen-komponen yang mempengaruhi akan mengubah sinar. LCD terbuat dari bahan kristal cair yang merupakan suatu komponen organik yang mempunyai sifat optic seperti benda padat meskipun bahan tetap cair. Contoh komponen itu adalah Kolesteril nonanoat dan P-azoxyanisole.

\section{Keypad 4 x 4}

Keypad digunakan sebagai media masukan dalam berbagai aplikasi elektronik. Rangkaian keypad berupa kaki baris dan kolom yang dapat dihubungkan dengan piranti luar. Bila salah satu tombol keypad ditekan maka keluaran yang dihasilkan berupa kombinasi baris dan kolom tersebut. Jenis keypad dibedakan berdasarkan jumlah baris dan kolomnya. Gambar 2.13 menunjukkan salah satu jenis keypad, yaitu keypad 4x4.

\section{ISD 2590}

Untuk menghasilkan output suara pada perancangan alat ini menggunakan ISD 2590 yang mempunyai kemampuan penyimpanan suara dengan durasi 90 detik. ISD 2590 dioperasikan dalam mode address bit, artinya setiap kata yang direkam mempunyai address sendiri. Address bit ini akan menggunakan logika bilangan biner.

\section{Rangkaian Driver}

Untuk menggerakan katup yang digerakan dengan motor maka diperlukan rangkaian driver yang berfungsi menghubungkan keluaran mikrokontroler ke motor penggerak . Rangkaian driver tersebut menggunakan relai yang berfungsi sebagai saklar bila diberi catu . Untuk rangkaian driver diperlihatkan dalam gambar Rangkaian driver menggunakan dioda yang diparalel dengan relai yang bertujuan untuk melindungi transistor terhadap transien yang diakibatkan oleh runtuhnya medan magnet relai tersebut (Coughlin, 1985).

\section{METODOLOGI PENELITIAN}

Jenis penelitian adalah rancang bangun alat dengan menguji coba alat sistem pengendali asap rokok dalam ruangan. Keluaran dari alat ini adalah sinyal output yang akan mengaktifkan jendela, fan, pengharum dan alarm

Sistem yang dirancang bertujuan untuk mengendalikan asap rokok dalam ruangan. Adapun perancangan alat yang akan digunakan dalam penelitian ini seperti pada gambar dibawah ini: 


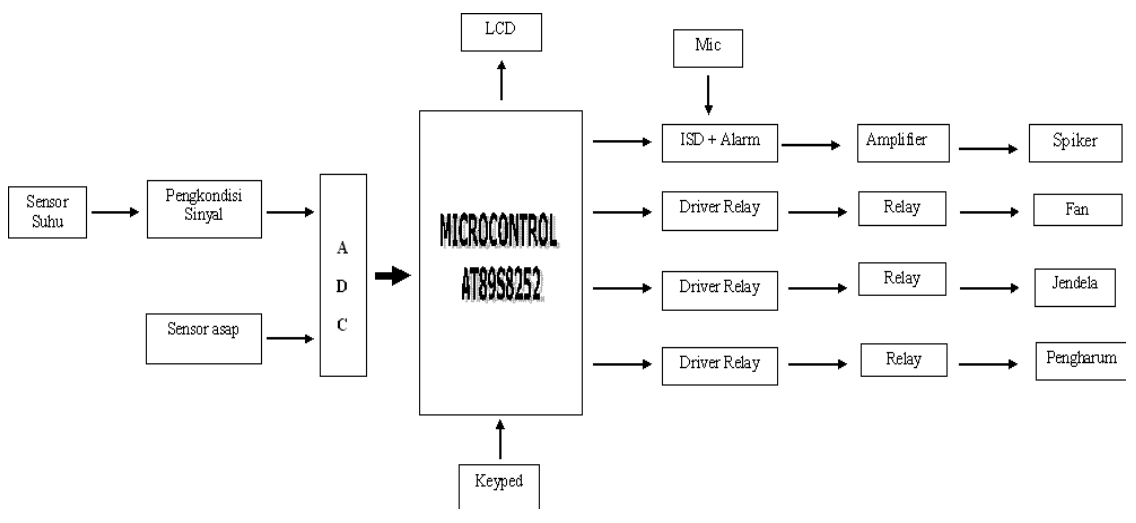

Gambar 1. Rancangan Alat

Secara singkat prinsip kerja alat secara keseluruhan adalah sebagi berikut:

Set poin konsentrasi asap rokok diatur 100 ppm, sedangkan set poin pada suhu diatur suhu $32^{\circ} \mathrm{C}$. Apabila sensor gas mendeteksi kadar gas hasil pembakaran yang terkandung dalam asap rokok memiliki konsentrasi lebih

dari 100 ppm dan sensor suhu mendeteksi suhu ruangan lebih dari $32^{\circ} \mathrm{C}$, maka jendela membuka, fan bekerja, dan alarm on. Setelah kadar gas hasil pembakaran berkurang hingga menunjukkan konsentrasi 100 ppm, dan suhu ruangan menunjukkan $32^{\circ} \mathrm{C}$, Jendela menutup, fan off, alarm off. kemudian pengharum bekerja. Suhu ruangan, dan konsentrasi asap rokok ditampilkan melalui LCD.

\section{HASIL DAN PEMBAHASAN}

\section{A. Tabel Pengukuran Sensor Suhu LM35}

Tabel 1. Hasil Pengujian Sensor Suhu LM35

\begin{tabular}{|c|c|c|c|}
\hline \multirow{2}{*}{$\begin{array}{c}\text { Suhu } \\
\left({ }^{\circ} \mathrm{C}\right)\end{array}$} & \multicolumn{2}{|c|}{$\mathrm{V}_{\text {out }}$ sensor suhu LM35 $(\mathrm{mV})$} & $\begin{array}{c}\text { Penyimpangan } \\
(\%)\end{array}$ \\
\cline { 2 - 4 } 25,0 & Perhitungan & Pengukuran & 0,40 \\
\hline 28,0 & 250 & 251 & 0,71 \\
\hline 31,0 & 310 & 282 & 0,32 \\
\hline 34,0 & 340 & 311 & 0,88 \\
\hline 37,0 & 370 & 343 & 0,54 \\
\hline 40,0 & 400 & 372 & 0,25 \\
\hline \multicolumn{3}{|c|}{$\sum$ penyimpangan } \\
\hline
\end{tabular}

Hasil pengujian pada sensor yang telah dilakukan, didapatkan data seperti pada tabel A1 dapat dikatakan bahwa tegangan output sensor suhu terhadap perubahan suhu adalah linier dan sesuai dengan spesifikasi sensor suhu LM35. Dari tabel A1 terlihat bahwa semakin besar nilai suhu yang diterima maka semakin besar nilai tegangan yang dibaca. Dari rata-rata simpangan sebesar $0,52 \%$, dapat disimpulkan bahwa antara 
perhitungan dan pengukuran didapatkan perbedaan yang minimum sehingga hasil pengujian sudah mendekati hasil perhitungan dan sesuai yang diharapkan.

\section{B. Tabel Pengukuran Pengkondisi Sinyal}

Tabel 2. Perhitungan Pengkondisi Sinyal untuk Sensor Suhu LM35

\begin{tabular}{|c|c|c|c|c|c|c|}
\hline $\begin{array}{c}\text { Suhu } \\
\left({ }^{\mathbf{o}} \mathbf{C}\right)\end{array}$ & Vin $(\mathbf{m V})$ & $\begin{array}{c}\text { Zero } \\
(\mathbf{m V})\end{array}$ & $\begin{array}{c}\text { Span } \\
(\mathbf{m V})\end{array}$ & $\begin{array}{c}\text { Vout } \\
(\mathbf{m V})\end{array}$ & ADC & LCD \\
\hline 25,0 & 250 & 263,4 & 19,6 & 0 & 0 & 25,0 \\
\hline 28,0 & 280 & 263,4 & 19,6 & 588 & 30 & 28,0 \\
\hline 31,0 & 310 & 263,4 & 19,6 & 1176 & 60 & 31,0 \\
\hline 34,0 & 340 & 263,4 & 19,6 & 1764 & 90 & 34,0 \\
\hline 37,0 & 370 & 263,4 & 19,6 & 2352 & 120 & 37,0 \\
\hline 40,0 & 400 & 263,4 & 19,6 & 2940 & 150 & 40,0 \\
\hline
\end{tabular}

Tabel 3. Hasil Pengujian Rangkaian Pengkondisi Sinyal

\begin{tabular}{|c|c|c|c|}
\hline \multirow{2}{*}{ Vin $(\mathrm{mV})$} & $\mathrm{V}_{\text {out }}$ Pengkondisi sinyal $(\mathrm{mV})$ & Penyimpangan \\
\cline { 2 - 3 } & Perhitungan & Pengukuran & $(\%)$ \\
\hline 250 & 0 & 0 & 0 \\
\hline 280 & 588 & 590 & 0,34 \\
\hline 310 & 1176 & 1182 & 0,51 \\
\hline 340 & 1764 & 1760 & 0,23 \\
\hline 370 & 2352 & 2355 & 0,13 \\
\hline 400 & 2940 & 2944 & 0,14 \\
\hline \multicolumn{3}{|c|}{$\sum$ penyimpangan } \\
\hline
\end{tabular}

Penguat sinyal dipakai karena tegangan keluaran dari sensor terlalu rendah dan harus dikuatkan agar sesuai dengan masukan yang dibutuhkan oleh ADC. Berdasarkan hasil pengujian pada tabel didapatkan simpangan rata-rata dari rangkaian penguat sinyal ini adalah sebesar $0,23 \%$. Dari simpangan rata-rata sebesar $0,23 \%$, dapat disimpulkan bahwa antara perhitungan dan pengukuran didapatkan perbedaan yang minim sehingga hasil pengujian sudah mendekati hasil perhitungan dan sesuai yang diharapkan.

\section{C.Tabel Pengukuran Sensor Asap TGS 2600}

Tabel 4. Data Perhitungan pada Grafik Sensor TGS 2600

\begin{tabular}{|c|c|c|c|c|}
\hline No & Rs & Ro & Vout & ppm \\
\hline 1 & 32,51 & 32,51 & 1,176 & 1 \\
\hline 2 & 29,25 & 32,51 & 1,272 & 25 \\
\hline 3 & 26,02 & 32,51 & 1,388 & 50 \\
\hline 4 & 22,75 & 32,51 & 1,526 & 75 \\
\hline 5 & 19,51 & 32,51 & 1,698 & 100 \\
\hline
\end{tabular}


Tabel 5. Data Perhitungan pada Grafik Sensor TGS 2600

\begin{tabular}{|c|c|c|c|c|}
\hline \multirow{2}{*}{ No } & ppm & \multicolumn{2}{|c|}{ Vout(mV) } & $\begin{array}{c}\text { Simpangan } \\
(\%)\end{array}$ \\
\cline { 2 - 5 } & & Teori & Pengukuran & 0,51 \\
\hline 1 & 1 & 1,176 & 1,182 & 0,55 \\
\hline 2 & 25 & 1,272 & 1,279 & 0,57 \\
\hline 3 & 50 & 1,388 & 1,396 & 0,85 \\
\hline 4 & 75 & 1,526 & 1,539 & 0,94 \\
\hline 5 & 100 & 1,698 & 1,714 & 3,42 \\
\hline \multicolumn{3}{|c|}{$\sum$ penyimpangan } \\
\hline
\end{tabular}

Dari tabel pengujian $\mathrm{V}_{\text {out }}$ sensor asap TGS 2600 membuktikan bahwa semakin besar konsentrasi gas (asap) yang kita berikan maka semakin besar $\mathrm{V}_{\text {out }^{-}}$nya. Ini membuktikan bahwa data teori dan data pengukuran sudah valid, dengan simpangan rata-rata sebesar $0,68 \%$.

\section{Tabel Pengukuran ADC PCF8591}

Tabel 6. Hasil pengujian ADC PCF8591 dengan Output Led

\begin{tabular}{|c|c|c|}
\hline \multirow{2}{*}{$\begin{array}{c}\text { Tegangan } \\
\text { masukan }(\mathrm{mV})\end{array}$} & \multicolumn{2}{|c|}{ Keluaran } \\
\cline { 2 - 3 } & Desimal & Biner \\
\hline 0 & 0 & 00000000 \\
\hline 588 & 30 & 01111000 \\
\hline 1176 & 60 & 00111100 \\
\hline 1764 & 90 & 01011010 \\
\hline 2352 & 120 & 00011110 \\
\hline 2940 & 150 & 01101001 \\
\hline
\end{tabular}

Tabel 7. Hasil pengujian ADC PCF8591 dan Penyimpangan suhu

\begin{tabular}{|c|c|c|c|}
\hline $\begin{array}{c}\text { Output ADC } \\
8 \text { bit (decimal) }\end{array}$ & $\begin{array}{c}\text { Suhu ukur } \\
\left({ }^{\circ} \mathrm{C}\right)\end{array}$ & $\begin{array}{c}\text { Suhu hitung } \\
\left({ }^{\circ} \mathrm{C}\right)\end{array}$ & $\begin{array}{c}\text { Simpangan } \\
(\%)\end{array}$ \\
\hline 0 & 25,0 & 25,21 & 0,84 \\
\hline 30 & 28,0 & 28,23 & 0,92 \\
\hline 60 & 31,0 & 31,18 & 0,58 \\
\hline 90 & 34,0 & 34,25 & 0,74 \\
\hline 120 & 37,0 & 37,23 & 0,62 \\
\hline 150 & 40,0 & 40,29 & 0,73 \\
\hline \multicolumn{3}{|c|}{ 2 penyimpangan } \\
\hline
\end{tabular}




\section{E. Tabel Pengukuran Driver Relay}

Tabel 8. hasil Pengujian Rangkaian Relay dan Driver Relay Fan

\begin{tabular}{|c|c|c|c|}
\hline Logic & V Logic & V Driver & fan \\
\hline 0 & 0,03 & 14,22 & ON \\
\hline 1 & 4,97 & 0,053 & OFF \\
\hline
\end{tabular}

Tabel 9. Hasil Pengujian Rangkaian Driver Relay Jendela

\begin{tabular}{|c|c|c|c|c|c|c|}
\hline \multicolumn{2}{|c|}{ Logic } & \multicolumn{2}{c|}{ V Logic } & \multicolumn{2}{c|}{ V Driver } & \multirow{2}{*}{ JENDELA } \\
\hline A & B & A & B & A & B & JEND \\
\hline 0 & 0 & 0,02 & 0,03 & 0,056 & 0,058 & Stop \\
\hline 0 & 1 & 0,02 & 4,96 & 0,056 & 14,67 & Buka \\
\hline 1 & 0 & 4,97 & 0,03 & 14,28 & 0,058 & Buka \\
\hline 1 & 1 & 4,97 & 4,96 & 14,28 & 14,67 & Stop \\
\hline
\end{tabular}

Tabel 10. Hasil Pengujian Rangkaian Driver Relay Pengharum

\begin{tabular}{|c|c|c|c|}
\hline Logic & V Logic & V Driver & PENGHARUM \\
\hline 0 & 0,02 & 0,60 & Semprot \\
\hline 1 & 4,98 & 14,16 & Stop \\
\hline
\end{tabular}

Berdasarkan hasil pengujian driver relay pada tabel 4.6 didapatkan tegangan yang dikeluarkan oleh mikrokontroler sebesar 0 dan 5 volt. Namun dalam kenyataannya tegangan ini tidak bisa digunakan secara langsung untuk menggerakkan beban. Hal ini disebabkan karena arus yang mampu dilewatkan oleh kaki-kaki mikrokontroler sangat kecil. Untuk itu perlu dipasang piranti yang mampu menguatkan arus, sehingga dapat digunakan untuk menggerakkan beban. Piranti ini biasa disebut dengan driver.

Pengendali utama dalam sistem ini adalah mikrokontroler AT89S8252. Bahasa program yang digunakan adalah bahasa assembler. Program ini bertujuan untuk menjalankan suatu alat untuk mengendalikan kesegaran udara dalam suatu ruangan secara otomatis dan memberikan informasi kepada semua orang yang ada dalam suatu ruangan tentang suhu dan konsentrasi asap dalam ruangan tersebut yang telah dimasukkan di mikrokontroler AT89S8252.

Pertama kita memasang semua rangkaian sesuai dengan skema. Pada Sistem ini mikrokontroler terlebih dahulu mendeteksi keadaan sensor suhu setelah itu dikuatkan oleh penguat sinyal dan sensor asap kemudian dikonversi oleh ADC yang akan dikirim ke Mikrokontroler. Pengendalian sistem secara keseluruhan berpusat pada mikrokontroler. Langkah-langkah atau alur jalannya kontrol yang dilakukan mikrokontroler sepenuhnya diatur oleh program utama mikrokontroler yang dalam hal ini menggunakan bahasa pemograman assembler. 
Berdasarkan pengujian secara keseluruhan yang telah dilakukan, diketahui bahwa: sensor suhu, rangkaian penguat, sensor asap, ADC, mikrokontroler, rangkaian LCD, keypad, alarm , driver relay fan, jendela dan pengharum. berjalan sesuai dengan perancangan. Setiap bagian dalam sistem pada perencanaan ini bekerja sesuai dengan kontrol masing-masing. Hal ini dilakukan dengan merangkai semua blok-blok yang ada menjadi satu sistem. Sistem ini di uji cobakan dengan melihat hasil keluaran yang diperoleh yakni berupa pegedalian udara dalam ruagan secara otomatis akibat asap rokok.

\section{KESIMPULAN}

Dari hasil penelitian dan pembahasan tentang sistem pengendali asap rokok dalam suatu ruangan dapat disimpulkan bahwa:

1. Piranti elektronik yang dibutuhkan dalam rangkaian pengendali asap rokok ini adalah Sensor suhu LM35, sensor asap TGS 2600, pengkondisi sinyal, ADC,MK AT89S8252, Driver relay, ISD, jendela, fan, pengharum. Alat ini dibuat dengan merangkai piranti-piranti elektronik yang menjadi suatu sistem yang dapat mendeteksi suhu dan mendeteksi asap rokok secara otomatis.

2. Secara keseluruhan alat yang dibuat, dapat bekerja dan berfungsi sebagaimana yang diharapkan, sehingga diharapkan dapat dimanfaatkan sebagai alat pengendali asap rokok dalm ruang tertutup. Mikrokonktroler AT89S8252 sebagai pengendali utama, cukup efisien karena membutuhkan perangkat keras yang sedikit serta kebutuhan sumber catu daya yang kecil.

\section{DAFTAR PUSTAKA}

Aditama, Tjandra Yoga. 1992. Rokok dan Kesehatan. Jakarta: UI Press.

Budiarto, Widodo. 2005. Perancangan Sistem dan Aplikasi Mikrokontroler. Jakarta: PT. Elex Media Komputindo

Figaro Engineering Incorporation. 2003. Version Change Of FIC93619A to FIC02667. http://www.figarousa@figarosensor.com. Tanggal akses 09 November 2009

Malvino, Albert Paul. 1985. Prinsip-prinsip elektronika Jilid 1, terjemahan M. Barmawi dan M. O Tjian, Ph. D. Jakarta: Erlangga.

Nalwan, Paulus Andi. 2003. Tehnik Antarmuka dan Pemrograman Mikontroller AT89C51. Jakarta:Elex Media Komputindo.

Philips, Semiconductors. 2003. Data Sheet PCF8591 8-bit A/D and D/A converter. http://www.semiconductors.philips.com.

Semiconductor, National. 2005. LM158/LM258/LM358/LM2904 Low Power DualOperational Amplifiers. http://www.national.com. Tanggal akses 14 Januari 2010 